\title{
Unmet needs in sexual health in bladder cancer patients: a systematic review of the evidence
}

\author{
Agustina Bessa ${ }^{1 *}$, Rebecca Martin², Christel Häggström ${ }^{1,3,4}$, Deborah Enting ${ }^{1,5}$, Suzanne Amery ${ }^{6}$, \\ Muhammad Shamim Khan ${ }^{6}$, Fidelma Cahill1', Harriet Wylie', Samantha Broadhead ${ }^{6}$, Kathryn Chatterton ${ }^{6}$, \\ Sachin Malde ${ }^{6}$, Rajesh Nair ${ }^{6}$, Ramesh Thurairaja ${ }^{6}$, Pardeep Kumar ${ }^{2}$, Anna Haire ${ }^{1}$, Saran Green ${ }^{1}$, Margaret Northover ${ }^{6}$, \\ Karen Briggs ${ }^{6}$ and Mieke Van Hemelrijck ${ }^{1}$
}

\begin{abstract}
Background: Bladder cancer (BC) treatment can have a detrimental effect on the sexual organs of patients and yet assessment of sexual health needs has been greatly overlooked for these patients compared to those who have undergone other cancer therapies.

Methods: This review was conducted in accordance with the Preferred Reporting Items for Systematic Reviews and Meta-analyses (PRISMA) guidelines in July 2019. Studies were identified by conducting searches for Medline (using the PubMed interface), the Cochrane Central Register of Controlled Trials (CENTRAL) and Ovid Gateway (Embase and Ovid) using a list of defined search terms.
\end{abstract}

Results: 15 out of 37 studies included men only, 10 studies women only and 11 both sexes. Most participants were aged 50 to 65 years. Most studies $(n=34)$ focused on muscle invasive BC and only three on non-muscle invasive BC. Measurements of sexual dysfunction, including erection, ejaculation, firmness and desire, were the most commonly used measurements to report sexual health in men. In women, lubrification/dryness, desire, orgasm and dyspareunia were the most commonly reported. Twenty-one studies evaluated sexual dysfunction based on validated questionnaires, two with a non-validated questionnaire and through interviewing participants.

Conclusion: While recognition of the importance of the inclusion of psychometric measurements to assess sexual health is growing, there is a lack of consistent measures to assess sexual health in BC. With the focus on QoL arising in cancer survivorship, further studies are needed to develop, standardize and implement use of sexual health questionnaires with appropriate psychometrics and social measures to evaluate QoL in BC patients.

Trial registration: "PROSPERO does not currently accept registrations for scoping reviews, literature reviews or mapping reviews. PROSPERO is therefore unable to accept your application or provide a registration number. This decision should not stop you from submitting your project for publication to a journal."

Keywords: Bladder cancer, Sexual health, Radical cystectomy, Health-related quality of life, Mental wellbeing

\footnotetext{
* Correspondence: Agustina.m.bessa@gmail.com

'King's College London, School of Cancer and Pharmaceutical Studies,

Translational Oncology \& Urology Research (TOUR), TOUR, Guy's Hospital, 3rd

Floor Bermondsey Wing, London SE1 9RT, UK

Full list of author information is available at the end of the article
}

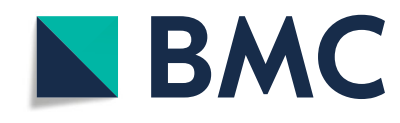

(c) The Author(s). 2020 Open Access This article is licensed under a Creative Commons Attribution 4.0 International License, which permits use, sharing, adaptation, distribution and reproduction in any medium or format, as long as you give appropriate credit to the original author(s) and the source, provide a link to the Creative Commons licence, and indicate if changes were made. The images or other third party material in this article are included in the article's Creative Commons licence, unless indicated otherwise in a credit line to the material. If material is not included in the article's Creative Commons licence and your intended use is not permitted by statutory regulation or exceeds the permitted use, you will need to obtain permission directly from the copyright holder. To view a copy of this licence, visit http://creativecommons.org/licenses/by/4.0/. The Creative Commons Public Domain Dedication waiver (http://creativecommons.org/publicdomain/zero/1.0/) applies to the data made available in this article, unless otherwise stated in a credit line to the data. 


\section{Background}

It is well known that the diagnosis and treatment of cancer causes significant physical, psychological, and social effects that interfere with a person's sexual health. Indeed, it has been estimated that between 40 and 100\% of cancer patients will experience a degree of sexual dysfunction [1]. Sexual dysfunction is characterized by disturbances in sexual desire and in the psychophysiological changes associated with the sexual response cycle in men and women or pain during intercourse [2,3]. The degree to which sexual dysfunction has been studied in different cancer types varies, with most studies performed in patients with prostate, breast or gynaecological cancers. The World Health Organization (WHO) defines sexual health as a state of physical, emotional, mental, and social wellbeing related to sexuality, and is not merely the absence of disease, dysfunction or infirmity [4]. Therefore, sexual health has to be evaluated holistically due to the complex interactions between biological, psychological, interpersonal and social/cultural factors [5], as all these factors may effect sexual function and wellbeing [6].

Bladder cancer $(\mathrm{BC})$ treatments are known to have a potential detrimental effect on both the genitals and the internal sexual organs of patients and yet it has been greatly overlooked compared to other cancer therapies [7]. Research of the treatment impact on sexual health has been widely identified as an unmet need in bladder cancer patients $[8,9]$.

Non-muscle invasive bladder cancer (NMIBC) accounts for about $70 \%$ of all bladder cancers [10] and those are mostly treated with transurethral resection of the bladder tumor (TURBT), followed by intravesical chemotherapy (22\%) or immunotherapy with bacillus CalmetteGuerin (BCG, 29\%) [11]. Muscle invasive bladder cancer (MIBC) are commonly treated with cystectomy $[11,12]$. The vast majority of studies currently available for bladder cancer focus on those who have undergone a radical cystectomy. Among those, many studies evaluate sexual-sparing radical cystectomy with the goal of reaching definitive oncologic control while attempting preservation of sexual function [13].

Current European Association of Urology (EAU 2019) guidelines [14] recommend that a standard radical cystectomy in men should include removal of the bladder, prostate, seminal vesical, distal ureters and regional lymph nodes, while in women removal of the bladder, entire urethra and adjacent vagina, uterus, distal ureters and regional lymph nodes is recommended. The guidelines also stated that a prostate-sparing radical cystectomy could be considered in carefully selected patients if oncologically safe. However, a sexual organ preserving operation in women is not advised, largely due to a paucity of available evidence [14]. Such treatments can induce serious complications and greatly impact the patient's body image and quality of life (QoL) [11]. Health-related QoL (HRQoL) can be formally defined as the extent to which one's usual or expected physical, emotional, and social wellbeing are affected by a medical condition or its treatment [15]. HRQoL issues of special concern to patients with $\mathrm{BC}$ include, among others, threats to body image and sexuality $[16,17]$.

With the focus on HRQoL arising in cancer survivorship, it is needed to closely address and evaluate posttreatment sexual dysfunction and offer goal-directed treatment. To date no detailed assessment of the overall burden of sexual health in bladder cancer patients has been made. This systematic literature review aimed to provide a consolidated overview of studies that address sexual health in bladder cancer patients. We specifically aimed to assess the methodology used to evaluate sexual health in terms of coverage and validation after $\mathrm{BC}$ treatment, which may provide a basis for future studies.

\section{Methods}

This review was conducted in accordance with the Preferred Reporting Items for Systematic Reviews and Metaanalyses (PRISMA) guidelines in July 2019. A detailed overview of the protocol is provided in Appendix 1.

\section{Search strategy and inclusion criteria}

Studies were identified by conducting searches for Medline (using the PubMed interface), the Cochrane Central Register of Controlled Trials (CENTRAL) and Ovid Gateway (Embase and Ovid) between May and July 2019 using a list of defined search terms (see Appendix 2). To be included in the analysis, the studies must have met the following criteria: study on the impact of bladder cancer treatment on sexual health/dysfunction and reported outcomes specifically for sexual health/dysfunction (e.g. erection, ejaculation, dryness).

\section{Data collection and analysis}

Initially, the titles of the studies were screened to identify the relevant studies. The abstracts and subsequently full texts were then carefully read to identify those which met the inclusion criteria. Two independent reviewers $(\mathrm{AB}$ and $\mathrm{RM}$ ) used the exact same search strategy and inclusion criteria and after each screening phase, a discussion was conducted with a third party (MVH) to match and decide on the included studies. Information on patient characteristics, number of study participants and type of treatment, as well as sexual health outcomes and mental wellbeing information was extracted from each study. The latter data was collected as sexual dysfunction may also have an impact on HRQoL through effects on mental wellbeing (4). The references of the included studies were also reviewed to ensure no relevant citation was missed.

\section{Results}

\section{Quantity of evidence identified}

The selection process for records to be included in the review was carried out according to PRISMA protocol, 
and this is demonstrated in a PRISMA flowchart in Fig. 1. A total of 667 records were collected from the literature search and 108 duplicates were removed. All titles were initially screened and 226 remained for abstracts screening. Of those, 71 remained for full text analysis. After the full text was read, 37 studies matched the inclusion and exclusion criteria and were included in this systematic review (Table 1, Appendix 3).

\section{Characteristics of the patient profiles}

Of the 37 studies included in the systematic review, 15 studies $(40.5 \%)$ included men only, 10 studies (27.0\%), women only and 12 studies (32.4\%) included both sexes. The exact number of women and men in the studies that included both sexes is not clearly described for all studies. With respect to age, in 28 studies (75.6\%) participants were

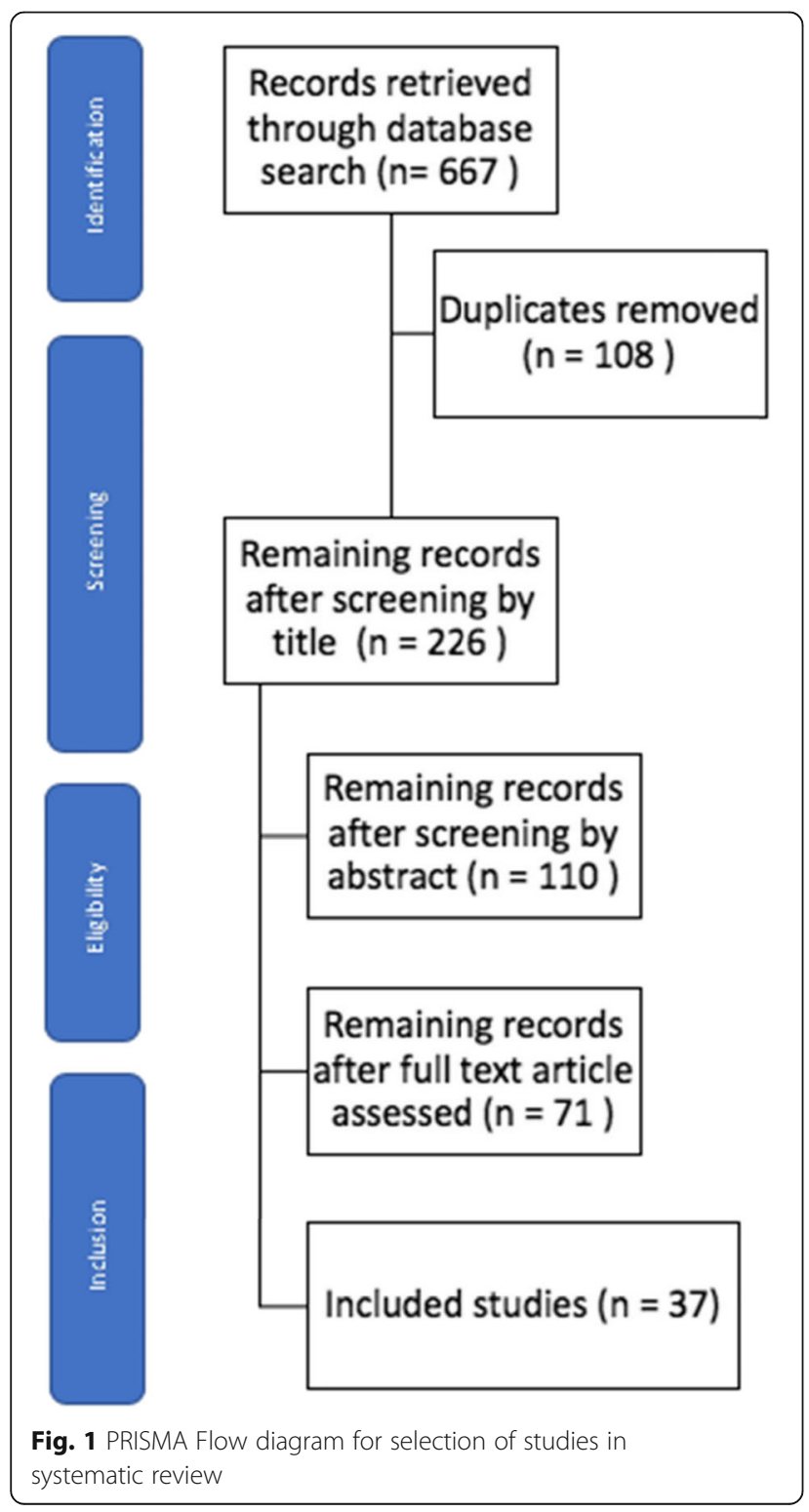

Table 1 Characteristics of the patient profile included in the studies

\begin{tabular}{ll}
\hline Patient profile & Studies (n) \\
\hline Sex (\%) & $15(39.5 \%)$ \\
Only men & $10(28.9 \%)$ \\
Only women & $12(32.4 \%)$ \\
Both sex & \\
Age & $5(13.5 \%)$ \\
$26-49$ & $28(75.6 \%)^{a}$ \\
$50-65$ & $4(10.8 \%)$ \\
$66-80$ & 0 \\
$81-95$ & \\
Disease stage (\%) & $34(91.9 \%)$ \\
MIBC & $3(8.10 \%)$ \\
NMIBC
\end{tabular}

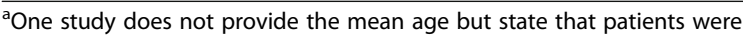
between 56 and 75 years old

aged between 50 to 65 years, in five studies (13.5\%) 26 to 49 years, in four studies (10.8\%) 66 to 80 years and none included participants above 80 years old. The vast majority of studies $[n=34(91.9 \%)]$ included MIBC and only three $(8.10 \%)$ focused on NMIBC. Patient profiles for each study are described in Table 1.

\section{Measurement of sexual health by sex}

Measurements of sexual dysfunction, including erection (73.0\%), ejaculation (35.1\%), firmness $(8.10 \%)$ and desire (18.9\%), were the most commonly used measurements to report sexual health in men. In women, lubrification/dryness $(27.0 \%)$, desire $(24.3 \%)$, orgasm $(27.0 \%)$ and dyspareunia (29.7\%) were the most commonly reported (Table 2 ).

\section{Comparison of sexual dysfunction outcome by treatments} and measurements

Thirty-three (89.2\%) studies addressed sexual dysfunction following radical cystectomy, one (2.7\%) following radical radiotherapy, one (2.7\%) after cystoscopy, and two (5.4\%) after other treatments for bladder cancer. There are no

Table 2 Measures of reported sexual dysfunction by sex

\begin{tabular}{lll}
\hline Sex & Measurement & Number of Studies (\%) \\
\hline Men & Erection & $27(73.0 \%)$ \\
& Firmness & $3(8.10 \%)$ \\
& Desire & $7(18.9 \%)$ \\
\multirow{3}{*}{ Women } & Ejaculation & $13(35.1 \%)$ \\
& Lubrification / Dryness & $10(27.0 \%)$ \\
& Desire & $9(24.3 \%)$ \\
& Orgasm & $10(27.0 \%)$ \\
& Dyspareunia & $11(29.7 \%)$ \\
\hline
\end{tabular}


studies looking at TURBT only. In four studies (10.8\%), participants were treated with drug therapy for their sexual dysfunction. Twenty-one studies (56.8\%) evaluated sexual dysfunction based on validated questionnaires, two (5.4\%) with a non-validated questionnaire and 14 (37.8\%) through interviewing participants.

\section{Patient and partners sexual satisfaction and mental wellbeing}

Seven studies evaluated patient sexual satisfaction and mental wellbeing (Table 3). None of those included both patient and partner satisfaction and mental wellbeing. One study included sexual satisfaction for both patients and partners, but did not report on mental wellbeing [18]. Regarding mental wellbeing, perception of body image [20, $22,24]$, worry about daily life [19], feeling of anxiety [23] and depression [22] were the most commonly reported outcomes. Six of those studies included patients with MIBC and one NMIBC. Six studies included patients in the age range of 50-65 years and two included patients $66-80$ years old. Overall, radical cystectomy was found to be associated with negative feelings regarding patient's body image and consequently a negative effect in sexual satisfaction. Patients who underwent a bladder sparing technique had a better perception of their body and a better sexual satisfaction. There is no consistency in the measurements used for sexual satisfaction and/or mental wellbeing: interviews and semi-structured interviews, sexual function index questionnaire, QoL questionnaire (SHIM and IFSF) and a functional assessment of cancer therapy questionnaire.

\section{Discussion}

Sexual dysfunction is a common phenomenon after bladder cancer treatment and yet sexual health is frequently overlooked. Of the 37 included studies included in our review, 15 studies included men only, 10 studies included women only and 12 studies included both sexes. Most studies included participants aged between 50 to 65 years. The majority of studies focused on patients with MIBC. The main outcomes measured in men were erection, ejaculation and desire and in women, lubrification/dryness, orgasm and dyspareunia. A broad range of measures were used in the studies including validated patient reported outcome tools, such as the SHIM and the IFSF questionnaire and interview-based studies.

One of the main observations following our systematic review is the heterogeneity in measurements used for sexual health. The SHIM tool is commonly used in prostate cancer and has also been most commonly used in the studies identified here. In female patients the available measurement tools are broader and less commonly implemented in practice. The most commonly used tool we found was the IFSF questionnaire. Both tools have been criticised for their lack of psychometric measures [25]. Indeed, the need for a robust measure of sexual function in bladder cancer that includes psychometric assessment is well recognised, but not yet developed [26]. Mohamed et al. (2014) identified unmet needs in MIBC patients and sexual function was a significant concern [8]. With no evidence of consistent clinical measures from practice, these findings are unsurprising. Patient and public involvement is needed to develop and include appropriate psychometrics measures in sexual health questionnaires. As previously noted by Peter Selby and Galina Velikova [27], patient input is essential, but the process is time consuming, sometimes quite expensive and can involve large numbers of patients or the general population to achieve meaningful results. Therefore, individuals and groups have tended to develop their own questionnaires which led to a lack of general consensus in the field and a confusing number of questionnaires.

Moreover, our systematic review highlights how sexual health may negatively impact on mental wellbeing and HRQoL - and hence indicates the need to address this gap for patients. As suggested by the definition of the WHO [4], sexual health has to be evaluated from a psychosocial perspective and not only the physical and physiological aspects. Although erectile dysfunction in men and physical and physiologic changes associated with cystectomy in women are the dominant factor driving sexual function, other causes of sexual dysfunction, such as depression or anxiety related to changed body image, distress regarding partner reaction to an altered body as well as the degree of problems that patients are experiencing due to their sexual function (bother), should be evaluated and managed.

Currently, HRQOL questionnaires like the Functional Assessment of Cancer Therapy - Bladder Cancer (FACT-BC) do include questions about interest in sex, while the Bladder Cancer Index (BCI) also includes questions about desire, arousal, sensation, and orgasm. Several EORTC questionnaires include a limited number of sexual functioning items. However, there is no single self-reported measure that covers the entire range of sexual health. Recently, the European Organization on Research and Treatment of Cancer (EORTC) developed an EORTC Sexual Health Questionnaire (EORTC SHQ-22) for assessing sexual health in cancer patients [28]. In addition to that, HRQOL assessment should target patient's current or very recent HRQOL status. This is of interest as (1) it has been suggested that patients overestimate their baseline HRQOL in the sexual function domains by $27 \%$ [29]; and (2) it would allow to better understand the degree of problems experienced by patients (measuring "bother"). It is also important to note that function and bother do not necessarily correlate as demonstrated by Letwin et al. [30] and that despite sexual health issues being an important concern to patients, they often experience difficulties in disclosing their complaints with health care providers or their partners. Lastly, as sexual wellbeing is closely 
Table 3 Patient and partner sexual satisfaction and mental wellbeing

\begin{tabular}{|c|c|c|c|c|}
\hline $\begin{array}{l}\text { Study } \\
\text { [ref] }\end{array}$ & Age range & Self-reported patient and partner satisfaction (if data available) & Mental wellbeing & Measurement \\
\hline [18] & $50-65$ & $\begin{array}{l}\text { Participants were found to have frequent erectile dysfunction, } \\
\text { ejaculation disorder, fear of hurting spouse/partner and } \\
\text { leakage during sexual intercourse. } \\
\text { The participants' spouse/partner were found to have fear of } \\
\text { hurting, decrease in sexual desire, inability to get pleasure/ } \\
\text { orgasm and avoiding sexual intercourse. }\end{array}$ & No data. & Interview \\
\hline [19] & $50-65$ & $\begin{array}{l}20 \% \text { of participants were not sexually satisfied. No data } \\
\text { regarding partner. }\end{array}$ & $\begin{array}{l}\text { Among the patients, } 42 \text { ( } 84 \%) \text { of them } \\
\text { were not feeling bad about their } \\
\text { bladder tumors and } 37(74 \%) \text { were } \\
\text { not worrying about their daily lives. } \\
\text { Moreover, } 12 \text { (24\%) patients were not } \\
\text { interested with sexuality. }\end{array}$ & $\begin{array}{l}\text { International Sexual } \\
\text { Function Index (IIEF-5) } \\
\text { and Female Sexual } \\
\text { Function Index (FSFI }\end{array}$ \\
\hline [20] & $50-65$ & $\begin{array}{l}\text { TMT was associated with higher sexual quality of life. No data } \\
\text { regarding partner. }\end{array}$ & $\begin{array}{l}\text { Compared with RC, the patients } \\
\text { treated with TMT reported significantly } \\
\text { better perception of their body image. } \\
\text { Patients who underwent TMT had } \\
\text { significantly fewer concerns about } \\
\text { their appearance and less life } \\
\text { interference from their cancer } \\
\text { diagnosis. Overall, the negative impact } \\
\text { of cancer was significantly less for } \\
\text { patients who had undergone TMT. }\end{array}$ & QoL questionnaire \\
\hline [21] & $66-80$ & $\begin{array}{l}37.5 \% \text { patients in the study agreed that treatment affected } \\
\text { their sexual function. No data regarding partner. }\end{array}$ & $\begin{array}{l}\text { At the time of diagnosis, patients of } \\
\text { both sexes reported relatively high } \\
\text { feelings of depression. }\end{array}$ & $\begin{array}{l}\text { Semi-structured } \\
\text { interviews. }\end{array}$ \\
\hline [22] & $66-80$ & $\begin{array}{l}\text { Forty-six patients enrolled in the study. Of those, only } 27 \\
\text { patients responded to the statement "I am satisfied with my } \\
\text { sex life". Approximately the same number of patients agreed } \\
\text { as disagreed, but the main response was neither to agree nor } \\
\text { to disagree with this statement. Thirty-one patients } \\
\text { responded to the statement "My sex life is not functioning". } \\
\text { Most patients agreed with this statement. Only } 23 \text { patients } \\
\text { responded to the statement "I am very happy with my sex } \\
\text { life". Again, most patients neither agreed nor disagreed. No } \\
\text { data regarding partner. }\end{array}$ & $\begin{array}{l}\text { The patients were asked whether the } \\
\text { change in their body appearance had } \\
\text { resulted in psychological problems } \\
\text { which had influenced their sex life. } \\
\text { Twenty-five patients (61\%) answered } \\
\text { that this was not the case, whereas } 11 \\
(27 \%) \text { answered that this was the case. }\end{array}$ & $\begin{array}{l}\text { Female Sexual Function } \\
\text { Index (FSFI) } \\
\text { questionnaire }\end{array}$ \\
\hline [23] & $50-65$ & $\begin{array}{l}\text { Radical cystectomy group, through the } 4 \text { measurements } \\
\text { points, started, stayed and ended on a lower level than the } \\
\text { case-control patients regarding overall sexual satisfaction. No } \\
\text { data regarding partner. }\end{array}$ & $\begin{array}{l}\text { The mean score for trait anxiety was } \\
\text { similar in both groups (RC and CC). } \\
\text { Only } 5.6 \% \text { of all RC patients had a } \\
\text { high anxious personality compared to } \\
20 \% \text { in the CC group, but this was not } \\
\text { statistically significant. }\end{array}$ & $\begin{array}{l}\text { International Index of } \\
\text { Erectile Function (FSFI) } \\
\text { and International Index } \\
\text { of Erectile Function } \\
\text { (IIEF) }\end{array}$ \\
\hline [24] & $50-65$ & $\begin{array}{l}\text { No data regarding sexual satisfaction. No data regarding } \\
\text { partner. }\end{array}$ & $\begin{array}{l}\text { Among patients who had undergone } \\
\mathrm{RC}, 8.5 \% \text { of the responders reported } \\
\text { being unhappy with their body image, } \\
\text { compared with the } 5 \% \text { reported by } \\
\text { patients in } \mathrm{Bl} \text { group. }\end{array}$ & $\begin{array}{l}\text { FACT-BL + additional } \\
\text { concerns }\end{array}$ \\
\hline
\end{tabular}

correlated with social interactions, patients' relationship status should also be considered when evaluating sexual wellbeing and its impact on HRQOL.

In our systematic review, most studies addressed sexual health in patients with MIBC who underwent radical cystectomy and only four studies focused on patients with NMIBC. This is potentially affecting the generalisibility of our observations as it is important to note that treatments for NMIBC and MIBC substantially differ, e.g. TURBT vs cystectomy. In a prospective study by Yoshimura et al. [31] on the impact of TURBT on QoL in patients with NMIBC, physical problems were found with the first
TURBT, but when the fourth TURBT was performed, patients appeared to have adapted to frequent operations, although their general QoL remained affected. For cystectomy patients, it has been shown that although relationships with friends were unchanged, relationships with spouse or partner were disturbed by sexual problems [32]. Partner response to the presence of an external appliance, such as stoma, may also strain intimate relationships and contribute to a dysfunctional sex life. Nevertheless, these observations highlight that 1) the threat of recurrence, multiple cystoscopies, TURBT, and intravesical instillations make QoL assessment in superficial bladder cancer 
challenging; 2) the importance of looking at sexual function in patients with bladder cancer in a broader way is needed, i.e. including both the physical perspective as well as the patients' partner and relationships.

There are limitations of this study that warrant further discussion. The analysis of the included studies was unable to provide an extensive coverage of sexual health in NMIBC patients for which the impact of treatment in sexual health and consequently QoL may also be significative. Due to the nature of the methods used to measure sexual health and the lack of psychometric measures, further research is needed to better understand the role of bladder cancer treatment and psychosocial factors of sexual functioning.

\section{Conclusion}

While recognition of the importance of the inclusion of psychometric measurements to assess sexual health is growing, this systematic review highlights the lack of consistent measures to assess sexual health in bladder cancer patients. With the focus on HRQoL arising in cancer survivorship, further studies are needed to develop, standardize and implement the use of sexual health questionnaires with appropriate psychometrics and social measures for bladder cancer patients.

\section{Appendix 1}

PROTOCOL: Systematic literature review on sexual health for patients with bladder cancer.

AIM: To consolidate an overview of studies that address sexual health in bladder cancer patients

\section{Objectives}

- Assess the methodology used to evaluate sexual health in terms of coverage and validation after bladder cancer treatment,

- Understand the role of bladder cancer treatment and psychosocial factors of sexual functioning

\section{METHODS}

Reports of current systematic review protocol adhere to the Preferred Items for Systematic Reviews and MetaAnalysis Protocol (PRISMA-P) checklist. The systematic review itself will adhere to the PRISMA.

\section{Criteria for considering studies for this review.}

\section{Types of studies.}

Any study that investigated sexual function or sexual dysfunction; any study where sexual function/sexual dysfunction/sexual health were measured by self-reports or an interview. Studies were original full text report in English and were published in peer-reviewed journals.

\section{Types of participants.}

The population of interest will be bladder cancer patients. Demographic factors are no exclusion criteria except for age ( $<18$ years of age).

\section{Types of outcomes measures.}

For both primary and secondary outcome measures, there will be no exclusion based on length of follow-up.

\section{Primary outcomes.}

Sexual function or sexual dysfunction in bladder cancer patients.

\section{Secondary outcomes.}

Treatment and psychosocial factors of sexual functioning.

SEARCH METHODS FOR IDENTIFICATION OF STUDIES.

\section{Electronic searches.}

The following electronic databases will be searched from inception until the search date: the Cochrane Central Register of Controlled Trials (CENTRAL), MEDLINE (using the PubMed interface), Embase (using the embase.com interface) and PsychINFO.

Data collection and analysis.

\section{Selection of studies.}

All references found through the search process will be downloaded in a database created by reference management software (Endnote). After removing duplicates in Endnote, all references will be imported into Covidence for screening purposes. Obviously irrelevant studies, based on title and abstract, will independently be excluded by two review authors. After screening the titles and abstracts, two review authors will independently assess fulltext reports for eligibility. Discrepancies will be discussed with a third review author. Reasons for exclusion of fulltexts will be documented. Studies will be excluded if no full-text is available. Abstracts in any other language than English will be excluded. There will be no language restriction for full texts, and translations will be carried out if necessary. If studies have multiple publications with the same outcome(s) reported, manuscripts with the longest follow-up will be selected for inclusion.

\section{Data extraction.}

For each included study in the review, at least the following information will be extracted:

- General information: report title, report ID, authors' names, country, contact address, language of publication and year of publication.

- Population and setting: population description (from which study participants are drawn), setting when applicable (eg, inpatient, outpatient, hospital setting, home setting and combination) and inclusion and exclusion criteria.

- Methods: aim of study, design, start and end date and duration of participation.

- Participants: number of participants, received treatment.

- Outcomes: outcome name, time points measured and reported.

- Results: measurement of sexual function and sexual dysfunction, psychosocial factors measured. 


\section{Dealing with missing data.}

If essential data are not available in the publication, we will first attempt to contact the study authors. If this is not possible, we will try to back-calculate from the data presented. If data will be obtained from other study authors, this will be reported in the review in a transparent manner. This way, we can keep in mind that these missing data obtained from study authors were not peer reviewed. Studies assessing lifestyle interventions may have issues with compliance. Therefore, reasons for missing data (eg, dropouts, losses to follow-up and withdrawals) will be carefully reported.

\section{Data synthesis.}

The findings from the included studies will be summarised in a table format.

\section{ETHICS AND DISSEMINATION.}

Ethics approval is not required, as no primary data will be collected. Results will be disseminated through a peer-reviewed publication.

The results of this systematic review could also have potential limitations in terms of biased results due to the nature of the patient reported outcomes.

\section{Appendix 2}

\section{Search strategy}

\section{PubMed.}

"Urinary Bladder Neoplasms"[MESH] OR "Urinary Bladder/abnormalities"[MESH] OR “Urinary bladder/ surgery"[MESH] OR "Carcinoma, Transitional Cell"[Mesh] OR "bladder cancer"[TIAB] OR "bladder cancers"[TIAB] OR "bladder carcinoma"[TIAB] OR "bladder carcinomas"[TIAB] OR "bladder malignancy"[TIAB] OR "bladder malignancies"[TIAB] OR "bladder neoplasm"[TIAB] OR "bladder neoplasm$s$ "[TIAB] OR "bladder tumor"[TIAB] OR "bladder tumors"[TIAB] OR "bladder tumour"[TIAB] OR "bladder tumours"[TIAB] OR "transitional cell carcinoma"[TIAB] OR "transitional cell carcinomas"[TIAB] OR "transitional cell cancer"[TIAB] OR "transitional cell cancers"[TIAB] OR "transitional cell malignancies"[TIAB] OR "transitional cell tumor"[TIAB] OR "transitional cell tumors"[TIAB] OR "transitional cell tumour"[TIAB] OR "transitional cell tumours"[TIAB]

\section{And}

"Sexual function" OR "sexual dysfunction" OR "wellbeing" OR "intimacy" OR "sexuality" OR "sexual physiology" OR "sexual physiopathology" "sexual heath"

\section{And}

"Cystectomy" OR "radical cystectomy" OR "partial cystectomy" OR "TURBT" OR "Transurethral resection of bladder tumour" OR "BCG" OR "chemotherapy" OR "Radiotherapy" OR "Bacillus Calmette-Guérin vaccine". Cochrane Library.

"Urinary Bladder Neoplasms" OR "Urinary Bladder abnormalities" OR "Urinary bladder surgery" OR "Carcinoma, Transitional Cell" OR "bladder cancer" OR "bladder cancers" OR "bladder carcinoma" OR "bladder carcinomas" OR "bladder malignancy" OR "bladder malignancies" OR "bladder neoplasm" OR "bladder neoplasms" OR "bladder tumor" OR "bladder tumors" OR "bladder tumour" OR "bladder tumours" OR "transitional cell carcinoma" OR "transitional cell carcinomas" OR "transitional cell cancer" OR "transitional cell cancers" OR "transitional cell malignancies" OR "transitional cell tumor" OR "transitional cell tumors" OR "transitional cell tumour" OR "transitional cell tumours"

\section{And}

"Sexual function" OR "sexual dysfunction" OR "wellbeing" OR "intimacy" OR "sexuality" OR "sexual physiology" OR "sexual physiopathology"

\section{And}

"Cystectomy" OR "radical cystectomy" OR "partial cystectomy" OR "TURBT" OR "Transurethral resection of bladder tumour" OR "BCG" OR "chemotherapy" OR "Radiotherapy" OR "Bacillus Calmette-Guérin vaccine".

\section{Embase.}

Urinary Bladder Neoplasms OR Urinary Bladder abnormalities OR Urinary bladder surgery OR Carcinoma, Transitional Cell OR bladder cancer OR bladder cancers OR bladder carcinoma OR bladder carcinomas OR bladder malignancy OR bladder malignancies OR bladder neoplasm OR bladder neoplasms OR bladder tumor OR bladder tumors OR bladder tumour OR bladder tumours OR transitional cell carcinoma OR transitional cell carcinomas OR transitional cell cancer OR transitional cell cancers OR transitional cell malignancies OR transitional cell tumor OR transitional cell tumors OR transitional cell tumour OR transitional cell tumours

\section{And}

Sexual function OR sexual dysfunction OR sexual health OR wellbeing OR intimacy OR sexuality OR sexual physiology OR sexual physiopathology

\section{And}

Cystectomy OR radical cystectomy OR partial cystectomy OR TURBT OR Transurethral resection of bladder tumour OR BCG OR chemotherapy OR Radiotherapy OR Bacillus Calmette Guerin vaccine OR Intravesical therapy OR Systemic immunotherapy. 


\section{Appendix 3}

Table 4 Treatment, measurement and outcome

\begin{tabular}{ll}
\hline $\begin{array}{l}\text { Study number } \\
\text { [ref] }\end{array}$ & Patient profile \\
\hline 1 & Group 1 comprised 58 \\
{$[33]$} & subjects (mean age 65 years) \\
& Group 2 comprised 50 \\
& subjects (mean age 61 years) \\
& Group 3 comprised 54 \\
& healthy subjects (mean age \\
& 63 years
\end{tabular}
technique and/or urinary diversion

Radical cystectomy
compared in ileal conduit

diversion, modified S-pouch and healthy subjects

healthy subjects (mean age 63 years 57 years)
Twenty patients and their spouses/partners (mean age 59 and 58 , respectively)
Radical cystectomy with prostate capsule sparing or nerve sparing and neobladder urinary diversion

Cystectomy followed by urostomy Interviews

Radical cystectomy with orthopaedic neobladder or uretrosigmoidostomy (continent group) or uretero-cutanoustomy or had ileal conduit (incontinent group)
Sexual Health Inventory for Men questionnaire (SHIM)

dysfunction was also evaluated for women and was not pronounced as in the men. Sexual desire was equally present in all groups and patients in group 1 expressed higher levels of dissatisfaction than the other two groups.

Compared to baseline, sexua function decreased similarly for both groups. 55 and 65\% of prostate capsule sparing and nerve sparing patients used aids or medications for erectile function, respectively.

Participants were found to have frequent erectile dysfunction, ejaculation disorder, fear of hurting spouse/partner and leakage during sexual intercourse.

The participants' spouse/partner were found to have fear of hurting, decrease in sexual desire, inability to get pleasure/orgasm and avoiding sexual intercourse.

Sexual Health Inventory for Men Questionnaire (SHIM)

Regarding sexual function, from 121 patients, 29 (23.9\%) underwent nerve-sparing and 59 (48.7\%) non nerve- sparing procedure. Erectile dysfunction affected $78.4 \%$ of them. There was a significant difference between both groups with lower degrees of erectile dysfunction in nerve-sparing group. After one year postoperatively, 19/29 (65.5\%) patients who underwent nerve-sparing radical cystectomy demonstrated spontaneous complete tumescence, $6(20.7 \%)$ achieved erections with the use of oral PDE5 inhibitors while 4 (13.8\%) required intra-cavernosal injection therapy. All patients treated with non-nerve sparing $\mathrm{RC}$ required intra-cavernosal injection therapy to achieve erections.

In total, 136 patients (86.1\%) maintained erectile function, of whom 27 (19.9\%) successfully used sildenafil, and 6 patients (4.4\%) used intra-cavernous injections.

Mild-moderate erectile dysfunction was found in men and sexual 
Table 4 Treatment, measurement and outcome (Continued)

Measurement Sexual function outcome

\begin{tabular}{lll}
\hline $\begin{array}{l}\text { Study number } \\
\text { [ref] }\end{array}$ & Patient profile & $\begin{array}{l}\text { Treatment, preserving } \\
\text { technique and/or urinary diversion }\end{array}$ \\
\hline & years) & \\
7 & $\begin{array}{l}\text { Eleven men underwent } \\
\text { conventional radical } \\
\text { cystoprostatectomy and 14 } \\
\text { patients had prostate-sparing } \\
\text { cystectomy (mean age 61.55 } \\
\text { and 57.5 years, respectively) }\end{array}$ & $\begin{array}{l}\text { Orthotopic neobladder } \\
\text { reconstruction after prostate- } \\
\text { sparing cystectomy and conven- }\end{array}$ \\
& $\begin{array}{ll}\text { Sixty-three men and 4 } 4 \\
\text { women (mean age 63 years) }\end{array}$ & $\begin{array}{l}\text { Robot-assisted radical cystoprostatectomy } \\
\text { cystoprostatectomy }\end{array}$ \\
\hline 38$]$ & &
\end{tabular}

5) and Female Sexual dysfunction in women. Function Index (FSFI)

International Index of After surgery, IIEF-5 scores in conven Erectile Function-5 tional radical cystoprostatectomy and (IIEF-5) prostate-sparing cystectomy groups were 3.7 and 16.0, respectively.

Interview cystoprostatectomy
Radical cystectomy and bladdersparing trimodality therapy underwent radical cystectomy and 64 patients underwent trimodality therapy (mean age 66 and 65 , respectively)
Twenty-two men and 8 women (mean age 67 years)
Radical cystectomy and urinary diversion
Semi-structured interviews
QoL questionnaire
With regard to sexual potency, twenty (43\%) patients with neobladder reported spontaneous erections prior to surgery, 14 (29\%) erectile

dysfunction of some degree, and in 13 $(28 \%)$ it is unknown. Of the 20 patients with normal sexual function prior to surgery, $90 \%$ had spontaneous erections that allowed them to have satisfactory sexual relations; of them, 3 managed it with the help of IPDE-5. Of the 14 patients who already re ported some prior erectile dysfunction, 9 achieved satisfactory erections with IPD5.

Male patients who had received trimodality therapy reported less difficulty gaining or maintaining an erection and decreased ejaculation problems compared with those who had undergone radical cystectomy. Patients who had undergone trimodality therapy also reported being less uncomfortable with being sexually intimate and less worried about contaminating their partner during sexual contact.

Overall, 25 and $18.18 \%$ of younger and older patients, respectively, reported a discussion with the physician regarding changes in sexual function. Following surgery, younger patients were more likely to report problems with sexual dysfunction.

Female Sexual Women who had reported good Radical cystectomy with preservation of genital organs and years (mean 24 years) were $30.77 \%$. Women of age range of 32-37 (mean 35 years) orthotopic ileal neobladder urinary diversion were $23.07 \%$ Women of age range of 40-54 (mean 49 years) were $48.5 \%$

Seventy-one women (mean age of 67 years).
Radical cystectomy tion Index (FSFI) questionnaire

Female Sexual Function Index (FSFI) questionnaire sexual function had DSFI score ranging from 20 to 32, which was reported by $84.61 \%$. One woman had a score of 15 , while another woman was not married and had no partner and she reported a score of zero.

Only $37 \%$ of the patients were sexually active post-surgery and those who were still sexually active tended to have less frequent sexual activity. A comparison of sexual desire before and after surgery found that 15 patients $(37 \%)$ reported that this was unchanged, 22 patients (54\%) that their desire for sex had decreased and one person that it had increased. Regarding ability to reach orgasm before and after surgery, 16 patients (39\%) reported that this was unchanged and 18 (44\%) that it was now harder to reach orgasm, while no 
Table 4 Treatment, measurement and outcome (Continued)

\begin{tabular}{lll}
\hline $\begin{array}{l}\text { Study number } \\
\text { [ref }]\end{array}$ & Patient profile & $\begin{array}{l}\text { Treatment, preserving } \\
\text { technique and/or urinary divers }\end{array}$ \\
\hline & & \\
13 & Sixty-eight men and 25 & $\begin{array}{l}\text { Bacillus Calmette-Guérin (BCG) } \\
\text { treatment }\end{array}$ \\
{$[40]$} & women (mean age 65 years)
\end{tabular}

Forty patients (mean age 58 years)

Eighteen patients undergoing radical cystectomy and 20 control (mean age 62.3 and 64.9 years, respectively)

Fifteen women patients (mean age of 42 years)
Prostate capsule sparing and nerve sparing cystectomies
Radical cystectomy

Internal genitalia sparing cystectomy years)
Radical cystectomy
Measurement Sexual function outcome

one reported that it was easier to reach orgasm.

Semi-structured $\quad$ For those individuals who were qualitative interviews sexually active, $60.0 \%$ of males experienced difficulty gaining or maintaining an erection and $43.1 \%$ of males had problems with ejaculation. Among sexually-active females, $62.5 \%$ experienced problems including vagi nal dryness. Nearly $50 \%$ of participants reported that it was very helpful to discuss concerns about sexual function with their partners.

Sexual Health Inventory for Men Questionnaire (SHIM)

Average sexual function at 12 months compared with baseline decreased by $1+/-11$ and $23+/-30$ points for prostate capsule sparing and nerve sparing, respectively. Of patients with prostate capsule sparing and nerve sparing cystectomy, 55 and 65\%, respectively, used aids or medication for erectile function.

International Index of Regarding erectile dysfunction, Erectile Function intercourse satisfaction, orgasmic (FSFI) and function, sexual desire and overall International Index of satisfaction-the radical cystectomy Erectile Function (IIEF) group started, stayed and ended on a lower level than the case control group throughout the study. No data reported for women.

Female Sexual Sexual intercourse was regained after Function Index (FSFI) 6 weeks, a duration which is significantly shorter than in women without genital preservation. The mean FSFI scores in the study group were significantly higher than in cystectomy women without genital sparing. Similarly, there were significant differences in favour of genital sparing cases in all domains of FSFI.

International Index of Most patients (88\%) had a score of Erectile Function less than 10 points on IIEF-5, 5.3\% of (IIEF-5) and visual patients showed 10-14 points, 4\% analogue scale (VAS). showed 15-19, and only 2.7\% showed equal to or more than 20 points. Be cause evaluation by IIEF-5 had not been performed before surgery, we could not determine the precise influence of orthotopic neobladder on sexual function.

Interview

All patients reported adequate sexual function with normal erections and satisfactory intercourse similar to that reported before surgery. The erectile activity was regained within the first 5 months after surgery. Two patients (50\%) preserved antegrade ejaculation the other two patients reported failure of ejaculation.

Interview
Erectile function is normal in all patients with satisfactory sexual intercourse. Antegrade ejaculation was 
Table 4 Treatment, measurement and outcome (Continued)

\begin{tabular}{|c|c|c|c|c|}
\hline $\begin{array}{l}\text { Study number } \\
\text { [ref] }\end{array}$ & Patient profile & $\begin{array}{l}\text { Treatment, preserving } \\
\text { technique and/or urinary diversion }\end{array}$ & Measurement & Sexual function outcome \\
\hline & & & & documented in six cases. \\
\hline $\begin{array}{l}20 \\
{[45]}\end{array}$ & $\begin{array}{l}\text { Four men and one woman } \\
\text { (mean age } 52.4 \text { years) }\end{array}$ & $\begin{array}{l}\text { Nerve sparing laparoscopic radical } \\
\text { cystectomy }\end{array}$ & $\begin{array}{l}\text { Female Sexual } \\
\text { Function Index (FSFI) } \\
\text { and International } \\
\text { Index of Erectile } \\
\text { Function score }\end{array}$ & $\begin{array}{l}\text { Sexual function was preserved in the } \\
\text { female patient and } 2 \text { of the } 4 \text { male } \\
\text { patients. }\end{array}$ \\
\hline $\begin{array}{l}21 \\
{[24]}\end{array}$ & $\begin{array}{l}\text { Eighty-two patients who had } \\
\text { undergone radical } \\
\text { cystectomy and } 177 \text { other } \\
\text { therapy (mean age } 64.4 \\
\text { years) }\end{array}$ & $\begin{array}{l}\text { Radical cystectomy and other } \\
\text { therapy }\end{array}$ & $\begin{array}{l}\text { FACT-BL + additional } \\
\text { concerns }\end{array}$ & $\begin{array}{l}\text { Patients with their bladders preserved } \\
\text { had more interest in sex when } \\
\text { compared with patients who had their } \\
\text { bladders removed. Twenty-one per } \\
\text { cent of respondents who had their } \\
\text { bladders preserved were not inter } \\
\text { ested in sex as compared with } 39 \% \\
\text { who underwent radical cystectomy. In } \\
\text { the radical cystectomy group, about } \\
89 \% \text { of the respondents could not } \\
\text { have and keep an erection, whereas in } \\
\text { the bladder intact group only } 32 \% \text { of } \\
\text { respondents could not have and keep } \\
\text { an erection. }\end{array}$ \\
\hline
\end{tabular}
Meinhardt and
Thirteen women (mean age Nerve sparing cystectomy with 56.7 years) urethra and vaginal sparing
Female Sexual Function Index (FSFI

All 6 patients were sexually active 1

Non nerve sparing and nerve sparing cystectomy

Female Sexual Function Index (FSF year after surgery. There is a significant vaginal dryness, a lack of arousal, and dyspareunia often led to discontinuation of sexual intercourse in the non-nerve-sparing group, with only 1 patient sexually active.

A reduction occurred in the mean 56.7 years) score for desire, arousal, pain, and
satisfaction. No change occurred in the mean score for orgasm or lubrication. One patient from the nerve-sparing group reported signifi cant dyspareunia after cystectomy that had resolved. All 6 patients had re sumed sexual activity at their 1-year follow-up visit.

Female Sexual Cystectomy and orthotopic ilea Twenty-nine women (mean age of 61 years) neobladder

The 11 of 17 patients who remained sexually active after cystectomy even had slight improvement. Six patients ceased to be sexually active postoperatively due to erectile dysfunction or partner death. One patient with interstitial cystitis became sexually active following cystectomy due to the loss of pelvic pain. Another 12 patients remained sexually inactive postoperatively.

Prostate sparing cystectomy and neobladder

Nerve-sparing radical cystectomy, orthotopic diversion, conduit diversion and cutaneous continent diversion
(Nieuwenhuijzen, Horenblas 2005)

Interviews on erection and ejaculatory function and the international index of erectile

function questionnaire 57.8 years).
Sexual Health Inventory for Men (SHIM)
Erectile function could be determined in 40 patients, and potency was maintained in $77.5 \%$, impaired in $12.5 \%$ and absent in $10 \%$.

Total mean SHIM score decreased after radical cystectomy. Of the 49 patients, 42 (86\%) did not have erections sufficient for vaginal penetration. Of these 42 patients, 22 (52\%) tried sildenafil citrate. Of these 22 patients, only 2 (9\%) responded positively. Only 9 (14\%) of 49 sexually 
Table 4 Treatment, measurement and outcome (Continued)

\begin{tabular}{lll}
\hline $\begin{array}{l}\text { Study number } \\
\text { [ref] }\end{array}$ & Patient profile & $\begin{array}{l}\text { Treatment, preserving } \\
\text { technique and/or urinary diversic }\end{array}$ \\
\hline & & \\
& & \\
27 & Twenty-eight patients (mean & Supra-ampullar cystectomy \\
{$[50]$} & age of 51.0 years). & \\
& & \\
28 & Twenty-seven women (mean & Radical cystectomy \\
{$[51]$} & age 54.79years) &
\end{tabular}

Measurement Sexual function outcome

active men were potent after surgery.

Of these 9 potent patients, 8 (89\%)

had undergone nerve-sparing radical cystectomy.

Self-administered questionnaire

Female Sexual Function Index (FSFI)
Potency was preserved in 26 patients (92.8\%), reporting satisfactory sexual intercourses; 15 patients (53.5\%) also maintained antegrade ejaculation allowing procreation in 3 cases.

The total mean baseline Index of Female Sexual Function score decreased. The most common symptoms reported by the patients included diminished ability or inability to achieve orgasm in 12 (45\%), decreased lubrication in 11 (41\%), decreased sexual desire in 10 (37\%), and dyspareunia in 6 patients (22\%). Only 13 (48\%) of the 27 patients were able to have successful vaginal intercourse, with 14 (52\%) reporting decreased satisfaction in overall sexual life after radical cystectomy. Eight partners (30\%) had a decrease in desire for sexual activity owing to apprehension after cancer diagnosis and treatment.

Structured interview Erectile function was insufficient in 3 men. In 5 men ejaculation was antegrade, in 4 it was retrograde and 1 had each experience from time to time. In the women lubrication and orgasmic feeling was reported to be normal after surgery.

Non-validated questionnaire 62.5 years)

Radical radiotherapy

Eight out of 17 patients felt that their sex life was a lot worse since radiotherapy and four felt that their sex life was a little. Five patients felt that their sex life was unchanged. No patient felt their sex life had improved. Despite this, seven patients were unconcerned that their sex life had changed. Only eight of those 12 patients whose sex life had deteriorated were concerned about the decline in their sexual function and indeed only two noted great concern over the decline.
Semi-structured interview
Of the men $20 \%$ were sexually inactive before cystectomy and 35\% had at least mild erection problems. These percentages increased to 50 and 91 , respectively, postoperatively. Most men who tried to reach orgasm after cystectomy could do so but $36 \%$ reported that they rarely or never had orgasms. About half of the men who were orgasmic after cystectomy complained that the intensity and pleasure of the sensation were reduced. However, the desire for sexual activity did not change as drastically as the ability to function. 
Table 4 Treatment, measurement and outcome (Continued)

\begin{tabular}{lll}
$\begin{array}{l}\text { Study number } \\
\text { [ref] }\end{array}$ & Patient profile & $\begin{array}{l}\text { Treatment, preserving } \\
\text { technique and/or urinary diversion }\end{array}$ \\
\hline$[55]$ & years) &
\end{tabular}

Measurement Sexual function outcome

Forty-two men (mean age 62.3 years)
Cystectomy, prostatectomy and vesiculcctomy

Radical cystectomy with urinary diversion
Interviews

Most cases partners were also interviewed.
Female Sexual Function Index (FSFI) activity included intercourse, although 4 women experienced severe dyspareunia and the other 3 active women had mild discomfort at first. One couple was not able to have intercourse until a session of sexual counselling 20 months postoperatively helped the wife to relax. One woman still has not been able to tolerate vaginal penetration, although she can reach orgasm through noncoital stimulation.

Levels of sexual desire remained normal in 7 women but patient 9 continued to experience low sexual desire and patient 4 lost her desire for sexual activity. Of the 7 women who resumed sexual activity 6 have been able to overcome most or all of the dyspareunia that they experienced at first. The pain and discomfort included a sensation of vaginal tightness in 5 women, including 1 of the 2 whose vagina was repaired by turning the posterior wall downwards. Three women had trouble with vaginal dryness despite use of a water-based lubricant. Only 1 woman produced enough natural vaginal lubrication for comfortable intercourse.

At the time of the interview, ten men had not attempted to resume sexual activity after the operation.

Only 3 patients were able to have penile erection after cystectomy. Although the remaining 24 patients were sexually active, they did not have a normal erection after the operation. Some of the men who achieved orgasm by masturbation reported a sensation of erection during orgasm.

Sexual relations had ceased age 52.3 years)

Seventy-six men (mean age of 57 years)
Cystectomy and bladder substitution
Interview
(26\%), while it was maintained in 54 patients (74\%). Among the postoperatively sexually active female various sexual dysfunctions were reported. Overall satisfaction among sexually active females was found to be the same as preoperatively in 14 patients (26\%), it had worsened in 32 (59.2\%) and was completely lost in eight patients (14.8\%).

After cystectomy, only $9 \%$ of all patients were still able to have an erection every second time or more often. Thirty-eight percent stated that they were still capable of orgasm, but a rather large proportion (21\%) claimed that they did not know. Of the 29 patients with retained orgasmic function, $41 \%$ reported no decrease in quality. Only $11 \%$ of conduit patients had unchanged or some coital activity post- operatively, as compared to $35 \%$ of bladder substitute patients report 
Table 4 Treatment, measurement and outcome (Continued)

\begin{tabular}{|c|c|c|c|c|}
\hline $\begin{array}{l}\text { Study number } \\
\text { [ref] }\end{array}$ & Patient profile & $\begin{array}{l}\text { Treatment, preserving } \\
\text { technique and/or urinary diversion }\end{array}$ & Measurement & Sexual function outcome \\
\hline & & & & ing unchanged or some activity. \\
\hline $\begin{array}{l}36 \\
{[58]}\end{array}$ & $\begin{array}{l}\text { Twenty-one men (mean age } \\
59.4 \text { years) }\end{array}$ & $\begin{array}{l}\text { Cystectomy with or without } \\
\text { urethrectomy }\end{array}$ & Interview & $\begin{array}{l}\text { All had tactile sexual activity and } \\
\text { preserved sexual desire. Around the } 12 \\
\text { in whom the urethra was preserved, } 4 \\
\text { had full and long lasting erection but } \\
\text { of short duration. These } 5 \text { patients, all } \\
\text { had erections that was satisfactory for } \\
\text { vaginal penetration and intercourse } \\
\text { and four were unable to achieve an } \\
\text { erection. Among those whom the } \\
\text { urethra was preserved, all but three } \\
\text { could experience orgasm. Among the } \\
\text { nine patients treated by cystectomy } \\
\text { and urethral excision two reported } \\
\text { that they had weak erections } \\
\text { insufficient for vaginal penetration and } \\
\text { intercourse. The remaining seven } \\
\text { failed to achieve erection. Three } \\
\text { patients in this group experienced } \\
\text { orgasm, one patient with a weak } \\
\text { erection and two of the seven } \\
\text { patients who could not achieve an } \\
\text { erection. }\end{array}$ \\
\hline $\begin{array}{l}37 \\
{[59]}\end{array}$ & $\begin{array}{l}18 \text { pre-menopausal women } \\
\text { (mean age of } 37.8 \text { years) }\end{array}$ & Radical cystectomy & $\begin{array}{l}\text { Female Sexual } \\
\text { Function Index (FSFI) } \\
\text { questionnaire }\end{array}$ & $\begin{array}{l}\text { Fifteen patients had an unchanged } \\
\text { sexual life, practicing sexual } \\
\text { intercourse at a once-weekly average } \\
\text { rate with normal orgasms. Three pa } \\
\text { tients complained of dyspareunia that } \\
\text { was managed with treatment. }\end{array}$ \\
\hline
\end{tabular}

\section{Abbreviations}

BC: Bladder cancer; BCG: Bacillus Calmette-Guérin; QoL: Quality of life; NMIBC: Non-muscle invasive bladder cancer; MIBC: Muscle invasive bladder cancer; HRQoL: Health-related quality of life; EORTC : European Organisation for Research and Treatment of Cancer; EORTC SHQ-22: European Organisation for Research and Treatment of Cancer Sexual health questionnaire - 22; TURBT: Trans urethral resection of bladder tumour; IFSF: Index of Female Sexual Function; SHIM: Sexual Health Inventory for Men; WHO: World health organisation

\section{Acknowledgements}

Not applicable.

\section{Authors' contributions}

all authors have read and approved the manuscript. Conception and design: $A B, R M, M V H$. Acquisition of data: AB, RM. Analysis and interpretation of data: $A B, R M, M V H$. Drafting of the manuscript: AB. Critical revision of the manuscript for important intellectual content: $\mathrm{CH}, \mathrm{DE}, \mathrm{SA}, \mathrm{MK}, \mathrm{FC}, \mathrm{HW}, \mathrm{SB}, \mathrm{KC}$, SM, RN, PK, AH, SG, MN, KB, RT, MVH.

\section{Funding}

Action Bladder Cancer UK and Arcobaleno Cancer Trust.

\section{Availability of data and materials}

Not applicable.

\section{Ethics approval and consent to participate}

Not applicable.

\section{Consent for publication}

Not applicable.

\section{Competing interests}

Not applicable.

\begin{abstract}
Author details
'King's College London, School of Cancer and Pharmaceutical Studies, Translational Oncology \& Urology Research (TOUR), TOUR, Guy's Hospital, 3rd Floor Bermondsey Wing, London SE1 9RT, UK. ${ }^{2}$ The Royal Marsden, Department Urology, London, UK. ${ }^{3}$ Department of Surgical Sciences, Uppsala University, Uppsala, Sweden. ${ }^{4}$ Department of Biobank Research, Umeå University, Umeå, Sweden. ${ }^{5}$ Department of Oncology, Guy's and St Thomas' NHS Foundation Trust, London, UK. ${ }^{6}$ Department of Urology, Guy's and St Thomas' NHS Foundation Trust, London, UK.
\end{abstract}

Received: 18 February 2020 Accepted: 22 May 2020

Published online: 03 June 2020

\section{References}

1. The Prevalence and Types of Sexual Dysfunction in People With Cancer | HealthCentral n.d. https://www.healthcentral.com/article/the-prevalenceand-types-of-sexual-dysfunction-in-people-with-cancer (Accessed 11 Aug 2019).

2. Laumann EO, Paik A, Rosen RC. Sexual dysfunction in the United States. JAMA. 1999;281:537. https://doi.org/10.1001/jama.281.6.537.

3. Levin RJ. Critically revisiting aspects of the human sexual response cycle of masters and Johnson: correcting errors and suggesting modifications. Sex Relatsh Ther. 2008:23:393-9. https://doi.org/10.1080/14681990802488816.

4. WHO | Sexual health. WHO 2016.

5. Wettergren L, Kent EE, Mitchell SA, Zebrack B, Lynch CF, Rubenstein MB, et al. Cancer negatively impacts on sexual function in adolescents and young adults: the AYA HOPE study. Psychooncology. 2017;26:1632-9. https://doi.org/10.1002/pon.4181.

6. Basson R, Rees P, Wang R, Montejo AL, Incrocci L. Sexual function in chronic illness. J Sex Med. 2010;7:374-88. https://doi.org/10.1111/j.1743-6109.2009. 01621.x.

7. Bhanvadia SK. Bladder Cancer survivorship. Curr Urol Rep. 2018;19:111. https://doi.org/10.1007/s11934-018-0860-6.

8. Mohamed NE, Chaoprang Herrera P, Hudson S, Revenson TA, Lee CT, Quale DZ, et al. Muscle invasive bladder cancer: examining survivor burden and 
unmet needs. J Urol. 2014;191:48-53. https://doi.org/10.1016/j.juro.2013.07. 062.

9. Paterson C, Jensen BT, Jensen JB, Nabi G. Unmet informational and supportive care needs of patients with muscle invasive bladder cancer: a systematic review of the evidence. Eur J Oncol Nurs. 2018;35:92-101. https://doi.org/10.1016/J.EJON.2018.05.006.

10. Isharwal S, Konety B. Non-muscle invasive bladder cancer risk stratification. Indian J Urol. 2015;31:289-96. https://doi.org/10.4103/0970-1591.166445.

11. Jeong CW. Quality of Life in Bladder Cancer Patients. BI. Cancer, Elsevier; 2018. p. 507-22. https://doi.org/10.1016/B978-0-12-809939-1.00028-X.

12. Bladder cancer: diagnosis and Bladder cancer: diagnosis and management management NICE guideline. 2015.

13. Pederzoli F, Campbell JD, Matsui H, Sopko NA, Bivalacqua TJ. Surgical factors associated with male and female sexual dysfunction after radical cystectomy: what do we know and how can we improve outcomes? Sex Med Rev. 2018;6:469-81. https://doi.org/10.1016/j.sxmr.2017.11.003.

14. EAU Guidelines | Uroweb n.d. https://uroweb.org/guidelines/ (Accessed 11 Aug 2019).

15. Moeen AM, Safwat AS, Gadelmoula MM, Moeen SM, Abonnoor AEl, Abbas WM, et al. Health related quality of life after urinary diversion. Which technique is better? J Egypt Natl Canc Inst. 2018:30:93-7. https://doi.org/10.1016/.j.nci.2018.08.001.

16. Bladder Cancer \&amp; Sexual Health | BladderCancer.net n.d. https:// bladdercancer.net/living/sexual-health/ (Accessed 22 Sept 2019).

17. Sex life | Bladder cancer | Cancer Research UK n.d. https://www. cancerresearchuk.org/about-cancer/bladder-cancer/living-with/sex-life (Accessed 22 Sept 2019).

18. Kandemir D, Oskay Ü. Sexual problems of patients with Urostomy: a qualitative study. Sex Disabil. 2017;35:331-40. https://doi.org/10.1007/ s11195-017-9494-8.

19. Bolat D, Celik S, Aydin ME, Aydogdu O, Gunlusoy B, Degirmenci T, et al. Assessment of the quality of life and sexual functions of patients followedup for non-muscle invasive bladder cancer: preliminary results of the prospective-descriptive study. Türk Üroloji Dergisi/Turkish J Urol. 2018;44: 393-8. https://doi.org/10.5152/tud.2018.30040.

20. Mak KS, Smith AB, Eidelman A, Clayman R, Niemierko A, Cheng J-S, et al. Quality of life in long-term survivors of muscle-invasive bladder Cancer. Int J Radiat Oncol. 2016;96:1028-36. https://doi.org/10.1016/J.JJROBP.2016.08.023.

21. Mohamed NE, Pisipati S, Lee CT, Goltz HH, Latini DM, Gilbert FS, et al. Unmet informational and supportive care needs of patients following cystectomy for bladder cancer based on age, sex, and treatment choices. Urol Oncol Semin Orig Investig. 2016;34:531.e7-531.e14. https://doi.org/10. 1016/J.UROLONC.2016.06.010.

22. Booth $B B$, Rasmussen A, Jensen JB. Evaluating sexual function in women after radical cystectomy as treatment for bladder cancer. Scand J Urol. 2015; 49:463-7. https://doi.org/10.3109/21681805.2015.1055589.

23. Goossens-Laan CA, PJM K, JLHR B, De Vries J. Patient-reported outcomes for patients undergoing radical cystectomy: a prospective case-control study. Support Care Cancer. 2014;22:189-200. https:/doi.org/10.1007/s00520-013-1946-9.

24. Allareddy V, Kennedy J, West MM, Konety BR. Quality of life in long-term survivors of bladder cancer. Cancer. 2006;106:2355-62. https://doi.org/10. 1002/cncr.21896.

25. Forbes MK, Baillie AJ, Schniering CA. Critical flaws in the female sexual function index and the international index of erectile function. J Sex Res. 2014:51:485-91. https://doi.org/10.1080/00224499.2013.876607.

26. Modh RA, Mulhall JP, Gilbert SM. Sexual dysfunction after cystectomy and urinary diversion. Nat Rev Urol. 2014;11:445-53. https://doi.org/10.1038/ nrurol.2014.151.

27. Selby P, Velikova G. Taking patient reported outcomes Centre stage in cancer research - why has it taken so long? Res Involv Engagem. 2018;4:25. https://doi.org/10.1186/s40900-018-0109-z

28. Oberguggenberger AS, Nagele E, Inwald EC, Tomaszewski K, Lanceley A, Nordin A, et al. Phase 1-3 of the cross-cultural development of an EORTC questionnaire for the assessment of sexual health in cancer patients: the EORTC SHQ-22. Cancer Med. 2018;7:635-45. https://doi.org/10.1002/cam4. 1338.

29. Litwin MS, McGuigan KA. Accuracy of recall in health-related quality-of-life assessment among men treated for prostate cancer. J Clin Oncol. 1999;17: 2882-8. https://doi.org/10.1200/JCO.1999.17.9.2882

30. Litwin MS, Hays RD, Fink A, Ganz PA, Leake B, Leach GE, et al. Quality-of-life outcomes in men treated for localized prostate cancer. JAMA. 1995;273: 129-35. https://doi.org/10.1001/jama.273.2.129.
31. Yoshimura K, Utsunomiya N, Ichioka K, Matsui Y, Terai A, Arai Y. Impact of superficial bladder cancer and transurethral resection on general healthrelated quality of life: an SF-36 survey. Urology. 2005;65:290-4. https://doi. org/10.1016/j.urology.2004.09.050.

32. Månsson A, Johnson G, Månsson W. Psychosocial adjustment to cystectomy for bladder carcinoma and effects on interpersonal relationships. Scand J Caring Sci. 1991;5:129-34.

33. Protogerou V, Moschou M, Antoniou N, Varkarakis J, Bamias A, Deliveliotis C. Modified S-pouch neobladder vs ileal conduit and a matched control population: a quality-of-life survey. BJU Int. 2004;94:350-4. https://doi.org/10. 1111/j.1464-410X.2004.04932.x.

34. Jacobs BL, Daignault S, Lee CT, Hafez KS, Montgomery JS, Montie JE, et al. Prostate capsule sparing versus nerve sparing radical cystectomy for bladder Cancer: results of a randomized, controlled trial. J Urol. 2015;193:6470. https://doi.org/10.1016/J.JURO.2014.07.090.

35. Moeen AM, Safwat AS, Gadelmoula MM, Moeen SM, Abonnoor AEl, Abbas WM, et al. Health related quality of life after urinary diversion. Which technique is better? J Egypt Natl Canc Inst. 2018;30:93-7. https://doi.org/10. 1016/J.JNCI.2018.08.001.

36. Voskuilen CS, Fransen van de Putte EE, Pérez-Reggeti Jl, van Werkhoven E, Mertens LS, van Rhijn BWG, et al. Prostate sparing cystectomy for bladder cancer: a two-center study. Eur J Surg Oncol. 2018;44:1446-52. https://doi. org/10.1016/.jejso.2018.05.032.

37. Chen PY, Chiang PH. Comparisons of quality of life and functional and oncological outcomes after Orthotopic Neobladder reconstruction: prostatesparing cystectomy versus conventional radical Cystoprostatectomy. Biomed Res Int. 2017;2017. https://doi.org/10.1155/2017/1983428.

38. Kanashiro A, Gaya JM, Palou J, Gausa L, Villavicencio H. Robot-assisted radical cystoprostatectomy: Analysis of the complications and oncological and functional aspects. Actas Urológicas Españolas. 2017;41:267-73. https:// doi.org/10.1016/j.acuroe.2017.03.006.

39. Wishahi $\mathrm{M}$, Elganozoury H. Survival up to 5-15 years in young women following genital sparing radical cystectomy and neobladder: oncological outcome and quality of life. Single-surgeon and single-institution experience. Cent Eur J Urol. 2015;68:141-5. https://doi.org/10.5173/ceju. 2015.475 .

40. Kowalkowski MA, Chandrashekar A, Amiel GE, Lerner SP, Wittmann DA, Latini DM, et al. Examining sexual dysfunction in non-muscle-invasive bladder cancer: results of cross-sectional mixed-methods research. Sex Med. 2014;2:141-51. https://doi.org/10.1002/sm2.24.

41. Ali-El-Dein B, Mosbah A, Osman Y, El-Tabey N, Abdel-latif M, Eraky I, et al. Preservation of the internal genital organs during radical cystectomy in selected women with bladder cancer: a report on 15 cases with long term follow-up. Eur J Surg Oncol. 2013;39:358-64. https://doi.org/10.1016/J.EJSO. 2013.02.004.

42. Takenaka A, Hara I, Soga H, Sakai I, Terakawa T, Muramaki M, et al. Assessment of long-term quality of life in patients with orthotopic neobladder followed for more than 5 years. Int Urol Nephrol. 2011;43:74954. https://doi.org/10.1007/s11255-010-9851-3.

43. Salem HK. Radical cystectomy with preservation of sexual function and fertility in patients with transitional cell carcinoma of the bladder: new technique. Int J Urol. 2007;14:294-8. https://doi.org/10.1111/j.1442-2042. 2007.01607.x.

44. Salem HK. Preservation of ejaculatory and erectile function after radical cystectomy for urothelial malignancy. J Egypt Natl Canc Inst. 2005;17:23944.

45. Lane BR, Finelli A, Moinzadeh A, Sharp DS, Ukimura O, Kaouk JH, et al. Nerve-sparing laparoscopic radical cystectomy: technique and initial outcomes. Urology. 2006;68:778-83. https://doi.org/10.1016/j.urology.2006. 05.027.

46. Nandipati KC, Bhat A, Zippe CD. Neurovascular preservation in female orthotopic radical cystectomy significantly improves sexual function. Urology. 2006;67:185-6. https://doi.org/10.1016/J.UROLOGY.2005.07.024.

47. Bhatt A, Nandipati K, Dhar N, Ulchaker J, Jones S, Rackley R, et al. Neurovascular preservation in orthotopic cystectomy: impact on female sexual function. Urology. 2006:67:742-5. https://doi.org/10.1016/j.urology. 2005.10.015

48. Volkmer BG, Gschwend JE, Herkommer K, Simon J, Küfer R, Hautmann RE. Cystectomy and orthotopic ileal neobladder: the impact on female sexuality. J Urol. 2004;172:2353-7. https://doi.org/10.1097/01.ju.0000145190. 84531.66 
49. Zippe CD, Raina R, Massanyi EZ, Agarwal A, Jones JS, Ulchaker J, et al. Sexual function after male radical cystectomy in a sexually active population. Urology. 2004;64:682-5. https://doi.org/10.1016/j.urology.2004.05.056.

50. Terrone C, Cracco C, Scarpa RM, Rossetti SR. Supra-ampullar cystectomy with preservation of sexual function and ileal orthotopic reservoir for bladder tumor: twenty years of experience. Eur Urol. 2004;46:264-70. https://doi.org/10.1016/j.eururo.2004.03.006.

51. Zippe CD, Raina R, Shah AD, Massanyi EZ, Agarwal A, Ulchaker J, et al. Female sexual dysfunction after radical cystectomy: a new outcome measure. Urology. 2004;63:1153-7. https:/doi.org/10.1016/j.urology.2003.12.034.

52. Miyao N, Adachi H, Sato Y, Horita H, Takahashi A, Masumori N, et al. Recovery of sexual function after nerve-sparing radical prostatectomy or cystectomy. Int J Urol. 2001;8:158-64. https://doi.org/10.1046/j.1442-2042. 2001.00274.x.

53. Little FA, Howard GCW. Sexual function following radical radiotherapy for bladder cancer. Radiother Oncol. 1998;49:157-61. https://doi.org/10.1016/ S0167-8140(98)00109-1.

54. Schover LR, Evans R, Von Eschenbach AC. Sexual rehabilitation and male radical cystectomy. J Urol. 1986;136:1015-7. https://doi.org/10.1016/500225347(17)45192-5.

55. Schove $L R$, Von Eschenbach $A C$. Sexual function and female radical cystectomy: a case series. J Urol. 2017;134:465-8. https://doi.org/10.1016/ s0022-5347(17)47242-9.

56. El-Bahnasawy MS, Osman Y, El-Hefnawy A, Hafez A, Abdel-Latif M, Mosbah $A$, et al. Radical cystectomy and urinary diversion in women: impact on sexual function. Scand J Urol Nephrol. 2011;45:332-8. https://doi.org/10. 3109/00365599.2011.585621.

57. Bjerre BD, Joh C. Sexological problems after cystectomy: bladder substitution compared with lleal conduit diversion: a questionnaire study of male patients. Scand J Urol Nephrol. 1998;32:187-93. https://doi.org/10. 1080/003655998750015557.

58. Tomić R, Sjödin JG. Sexual function in men after radical cystectomy with or without urethrectomy. Scand J Urol Nephrol. 1992;26:127-9.

59. Moursy EES, Eldahshoursy MZ, Gamal WM, Badawy AA. Orthotopic genital sparing radical cystectomy in pre-menopausal women with muscle-invasive bladder carcinoma: a prospective study. Indian J Urol. 2016;32:65-70. https://doi.org/10.4103/0970-1591.173112.

\section{Publisher's Note}

Springer Nature remains neutral with regard to jurisdictional claims in published maps and institutional affiliations.

Ready to submit your research? Choose BMC and benefit from:

- fast, convenient online submission

- thorough peer review by experienced researchers in your field

- rapid publication on acceptance

- support for research data, including large and complex data types

- gold Open Access which fosters wider collaboration and increased citations

- maximum visibility for your research: over $100 \mathrm{M}$ website views per year

At $\mathrm{BMC}$, research is always in progress.

Learn more biomedcentral.com/submissions 